OPEN ACCESS

Edited by:

David Ezra,

Agricultural Research Organization

(ARO), Israel

Reviewed by:

Waheed Akram,

BECS Center for Research and

Innovation, Pakistan

Marika Pellegrini,

University of L'Aquila, Italy

*Correspondence:

Donald L. Smith

donald.smith@mcgill.ca

Specialty section:

This article was submitted to

Disease Management,

a section of the journa

Frontiers in Agronomy

Received: 02 December 2021

Accepted: 17 January 2022

Published: 08 March 2022

Citation:

Riaz M, Mahmood R, Antar M, Akhtar N, Khan SN, Anjum MA and

Smith DL (2022) A Bacterial Consortium and Synthetic Fertilizer Based Biocontrol Approach Against

Potato Rot Disease "Neocosmospora rubicola". Front. Agron. 4:828070. doi: 10.3389/fagro.2022.828070

\section{A Bacterial Consortium and Synthetic Fertilizer Based Biocontrol Approach Against Potato Rot Disease "Neocosmospora rubicola"}

\author{
Muhammad Riaz ${ }^{1,2}$, Rashid Mahmood ${ }^{3}$, Mohammed Antar ${ }^{2}$, Naureen Akhtar ${ }^{1,4}$, \\ Salik Nawaz Khan ${ }^{1}$, Muhammad Ashfaq Anjum ${ }^{5}$ and Donald L. Smith ${ }^{2 *}$
}

${ }^{1}$ Department of Plant Pathology, University of the Punjab, Lahore, Pakistan, ${ }^{2}$ Department of Plant Science, McGill University, Montreal, QC, Canada, ${ }^{3}$ Department of Soil Science, University of the Punjab, Lahore, Pakistan, ${ }^{4}$ Monash Institute of Pharmaceutical Sciences, Faculty of Pharmacy and Pharmaceutical Sciences, Monash University, Melbourne, VIC, Australia, ${ }^{5}$ Soil Bacteriology Section, Ayub Agriculture Research Institute, Faisalabad, Pakistan

Conventional management of stem rot disease of potato, caused by Neocosmospora rubicola, through fungicide application is an environmentally unfavorable practice that calls for an alternative biocontrol approach. Plant growth-promoting bacteria (PGPB) are known to not only promote plant growth but also control diseases caused by various fungi. The study was designed to evaluate the potential of three strains of PGPB and synthetic fertilizer to manage stem rot of potatoes. In the first experiment, PGPB strains Azotobacter chroococcum, Azospirillum lipoferum, and Pseudomonas putida and their combinations were evaluated on PDA medium against $N$. rubicola using the dual culture technique. All three bacterial strains were found effective in reducing the radial growth of the fungus maximum up to $91 \%$. In the second experiment, in the presence of half and full recommended doses of fertilizer nitrogen $(\mathrm{N})$ and phosphorus $(\mathrm{P})$, the potato growing medium was inoculated with $N$. rubicola alone, and with combinations of $N$. rubicola and PGPB strains (bacterial formulation; BF). N. rubicola increased stem and tuber rot, and decreased tuber weight by $11 \%$ compared to the control. On the other hand, sole inoculation with BF significantly increased tuber weight. In addition, a combined inoculation of $N$. rubicola and $\mathrm{BF}$, or $N$. rubicola inoculation a week prior to BF inoculation did not affect tuber weight compared to control. However, inoculation of BF a week prior to N. rubicola, controlled rot symptoms and increased tuber weight by $32 \%$. An increase in $\mathrm{P}$ application favored the PGPB strains in controlling rot in tubers. The interaction effect of fertilizer $\mathrm{N}$ with the inoculation combinations was non-significant; however, the main impact of $\mathrm{N}$ was to increase rot in tubers and decrease in potato stems. Hence a prerequisite application of PGPB formulation proved to be an effective tool against N. rubicola infestation in potatoes.

Keywords: Neocosmospora rubicola, potato stem rot, Azotobacter chroococcum, Azospirillum lipoferum, Pseudomonas putida, bacterial formulation, biofertilizer 


\section{INTRODUCTION}

Potato (Solanum tuberosum L.) is one of the most important staple crops, and its long-term cultivation faces a significant threat of plant diseases (Dahal et al., 2019). These diseases are frequently managed by conventional agricultural practices, particularly by using various types of fungicides, which have serious environmental concerns (Chandra et al., 2020; My et al., 2021). Furthermore, sole and excessive use of chemical fertilizers to support intensive cropping systems also negatively impacts the environment by causing soil infertility, groundwater contamination, climate change, and imbalance of soil and water ecosystems (Liu et al., 2015; Besser and Hamed, 2021). Nutrient management by integrating inorganic fertilizers, manure, and biofertilizers has beneficial effects over the sole application of chemical fertilizers (Tafesse and Leta, 2019). Plant growth-promoting bacteria (PGPB) from biofertilizers promote plant growth through biological nitrogen fixation, phosphate solubilization, micronutrient solubilization, biosynthesis of phytohormones and other plant growth-promoting substances. Some PGPB also exhibits biocontrol properties and show antagonistic activity against various pathogenic fungi of crop plants (Mohammadi and Sohrabi, 2012; Pellegrini et al., 2020).

The rhizosphere is the soil around plant roots, where microbes mediate complex processes, and it is a hotspot for microbial community interactions (Paterson and Mwafulirwa, 2021). The plethora of microbial communities found in the rhizosphere comprises bacteria that are hostile to other microbes (Smith et al., 2015; Antar et al., 2021). These antagonistic bacteria interfere with pathogen growth and act as predators for other microbes (Chandra et al., 2020). The antagonistic bacteria play a vital role in the rhizospheric zone as a biocontrol agent and suppress phytopathogenic fungi (Anith et al., 2021). Several PGPB, in addition to their influence on plant growth and function through phytohormone synthesis, have been explored for their antifungal potential against many phytopathogens.

Most potential and widely reported PGPB genera associated with solanaceous crops to include Alcaligenes, Arthrobacter, Azospirillum, Azotobacter, Burkholderia, Enterobacter, Klebsiella, Pseudomonas, Serratia, and endophytic bacteria such as Bacillus, Erwinia, and Xanthomonas (Smith et al., 2015; Çevik and Ogutcu, 2020; Kumari et al., 2021). It has been reported that PGPB such as Azotobacter chroococcum, Azospirillum lipoferum, and Pseudomonas putida have the ability to produce siderophores, indole-3-acetic acid (IAA), hydrogen cyanide (HCN), and solubilize phosphate, act as biological control agent and enhance plant growth and development of potato (Sepehrnush et al., 2018). Azotobacter chroococcum naturally exists in the rhizosphere of various crops, releases some plant growth hormones and is capable of nitrogen fixation at about $20 \mathrm{~kg} \mathrm{~N} \mathrm{ha}{ }^{-1}$ year $^{-1}$ (Kumar et al., 2018; Song et al., 2021). Maheshwari et al. (2012) demonstrated that the strain TRA2 of A. chroococcum, an isolate of the wheat rhizosphere, showed strong antagonistic activity against root rot fungus Macrophomina phaseolina and Fusarium oxysporum and improved plant growth of wheat. Azospirillum lipoferum, a freeliving nitrogen-fixing bacterium, also produces phytohormones to promote the growth of inoculated plants, particularly under stress conditions (Czarnes et al., 2020; Batabyal, 2021). Pseudomonas putida, a Gram-negative bacterium, benefits crop plants by acting as a phosphate solubilizer and biocontrol agent (Sun et al., 2017; Takishita et al., 2021). The bacterium has a Type VI Secretion System (T6SS) to kill phytopathogens, which is important in its biocontrol portfolio (Borrero De Acuña and Bernal, 2021). It was found effective for a number of destructive plant pathogens like F. oxysporum in tomato, Rhizoctonia solani and Pectobacterium atrosepticum in potato and Sclerotinia sclerotiorum in lettuce (Bernal et al., 2017; Durán et al., 2021). Siderophores produced by P. putida can also improve the iron nutrition of crop plants (Meliani et al., 2017). Due to their various beneficial characteristics, A. chroococcum, A. lipoferum, and P. putida are used as PGPB in biofertilizers.

Neocosmospora rubicola is a filamentous fungus in the family Nectriaceae. It causes stem rot of Pitaya (Hylocereus costaricensis) in China (Zheng et al., 2018), root rot of Glycyrrhiza uralensis in Korea (Kim et al., 2017), and stem rot of potatoes in Pakistan (Riaz et al., 2020). Under laboratory conditions, the pathogen grows optimally at $26^{\circ} \mathrm{C}$ and near-neutral $\mathrm{pH}$ (Riaz et al., 2020). This favorable to the pathogen temperature $\left(26^{\circ} \mathrm{C}\right)$ prevails in many potato growing areas of the world. An occurrence frequency percentage of $\mathrm{N}$. rubicola was found to vary from 18 to $89 \%$ during a survey of potato fields of seven districts of Punjab, Pakistan (unpublished data).

The present study was designed to determine if PGPB A. chroococcum, A. lipoferum, and P. putida have the potential to suppress N. rubicola and its infestation to potato plants. The performance of the PGPB was evaluated against the pathogen in interaction with nitrogen $(\mathrm{N})$ and phosphorus $(\mathrm{P})$ nutrition of potato plants.

\section{MATERIALS AND METHODS}

\section{Isolation and Identification of Neocosmospora rubicola}

Neocosmospora rubicola was isolated from rotting potato stems collected during a survey of potato fields at Kot Radha Kishan $\left(31^{\circ} 10^{\prime} 21 \mathrm{~N}, 74^{\circ} 5^{\prime} 59 \mathrm{E}\right)$, district Kasur, Punjab, Pakistan. For fungal isolation, the infected stem was sterilized with $10 \%$ sodium hypochlorite $(\mathrm{NaClO})$ for $30 \mathrm{~s}$, and pieces (2 $\mathrm{mm}^{2}$ ) of the stem were incubated on potato dextrose agar (PDA) followed by purification through single spore inoculation (Muhammad et al., 2018; Zheng et al., 2018). Morphological identification of the fungus was conducted by the First Fungal Culture Bank of Pakistan (FCBP) as Neocosmospora genus. For species-level identification, genomic DNA of the fungus was isolated (Shafique et al., 2019) to perform PCR using two primers: Internal Transcribed Spacer (ITS) of rDNA and partial beta-tubulin gene (Park et al., 2012). PCR products were sequenced by SolGent (Daejeon, Korea). The acquired nucleotide sequences were deposited at GenBank (rDNA-ITS regions ID: MG976818 and partial beta-tubulin gene ID: MH016281) and differentiated from the pool of nucleotide sequences in GenBank by BLAST. BLAST results indicated that the present fungal 
strain's rDNA-ITS and atrial beta-tubulin genes were $100 \%$ similar to their corresponding sequences of $N$. rubicola strain CBS 320.73 submitted under the accession numbers KM231799 and KM232061. A pathogenicity test of N. rubicola as a causal agent of potato stem rot was performed. Further details of isolation, identification and pathogenicity test are described in our previous publication (Riaz et al., 2020).

\section{In-vitro Evaluation of PGPB Strains Against N. rubicola}

Pure cultures of three PGPB, namely A. chroococcum, A. lipoferum, and $P$. putida, were obtained from the Bacteriology section of Ayub Agriculture Research Institute (AARI) Faisalabad, Pakistan. This institute uses these PGPB to form a biofertilizer commercially available in the local market with the trade name of Faslon ka Jraseemi Teka (FKJT). The inhibition potential of PGPB strains against N. rubicola was evaluated using in-vitro dual culture techniques (Khruengsai et al., 2021). In this experiment, a solidified PDA Petri plate was an experimental replicate/unit. One $4 \mathrm{~mm}$ diameter mycelial disc from the margin of N. rubicola 7 days old culture was used to inoculate each agar-solidified PDA Petri plate by making the same size hole at the PDA center in the plate. The treatment plan was comprised of bacterial strains viz. A. chroococcum (Ac), A. lipoferum (Al), P. putida (Pp), $\mathrm{Ac}+\mathrm{Al}, \mathrm{Ac}+\mathrm{Pp}, \mathrm{Al}+\mathrm{Pp}$ and $\mathrm{Ac}+\mathrm{Al}+\mathrm{Pp}$, which were streaked $2 \mathrm{~cm}$ away from the central mycelial disc. The streaking was performed by making about $2 \mathrm{~cm}$ long single lines on three sides of the central disc using a sterilized wire loop. The experiment was conducted according to a completely randomized design (CRD), where each treatment was replicated three times. Petri plates were then incubated at $26^{\circ} \mathrm{C}$ for 5 days. After incubation, the colony diameter of the fungal growth in each replicate was measured from the same three sides where streaking was performed, and averages were used in subsequent statistical analyses.

\section{Evaluation of Synthetic Fertilizer and Inoculation With $\boldsymbol{N}$. rubicola and PGPB Formulation on Growth and Yield of Potato}

The experiment was conducted in plastic pots, $30 \mathrm{~cm}$ in height and $30 \mathrm{~cm}$ in diameter, after filling with $12 \mathrm{~kg}$ of loamy soil (Table 1). The experimental design was three times replicated $\mathrm{CRD}$ with $\mathrm{N}$ application rate, $\mathrm{P}$ application rate, and inoculation combination (IC) of $N$. rubicola $(\mathrm{Nr})$ and/or PGP bacterial formulation $(\mathrm{BF})$ as three experimental factors. The plan was comprised of half and full recommended rates of N (125 and $250 \mathrm{~kg} \mathrm{~N} \mathrm{ha}^{-1}$ ), half and full recommended rates of $\mathrm{P}$ (60 and $120 \mathrm{~kg} \mathrm{P}_{2} \mathrm{O}_{5} \mathrm{ha}^{-1}$ ), and six IC's of $\mathrm{Nr}$ and BF, i.e., no inoculation,

TABLE 1 | Chemical properties of loamy soil used in the experiment.

\begin{tabular}{|c|c|c|c|c|c|}
\hline \multirow[t]{2}{*}{ Soil type } & \multicolumn{5}{|c|}{ Chemical analysis } \\
\hline & $\mathrm{pH}$ & CEC (dS m $\left.{ }^{-1}\right)$ & \%O.M & $\mathbf{P}(\mathrm{ppm})$ & K (ppm) \\
\hline Loam & 7.8 & 1.5 & 0.69 & 14.3 & 302 \\
\hline
\end{tabular}

and inoculation with $\mathrm{Nr}, \mathrm{BF}, \mathrm{Nr}+\mathrm{BF}, \mathrm{Nr}$ followed by $\mathrm{BF}$ with a week interval and BF followed by $\mathrm{Nr}$ with a week interval. The recommended rates of $\mathrm{N}$ and $\mathrm{P}$ for potatoes were obtained from the literature published by Pakistan Agriculture Research Council (PARC) for the farming community (PARC-Pakistan Agriculture Research Council, 2002).

Each experimental unit was a pot in which three seed potatoes (Kuroda variety of Agrico, UK) of uniform size and the same number of buds were cultivated. Prior to planting, potassium sulfate at the rate of $125 \mathrm{~kg} \mathrm{~K}_{2} \mathrm{O} \mathrm{ha}{ }^{-1}$, whole $\mathrm{P}$ as single super phosphate (SSP) and half of the $\mathrm{N}$ as urea was applied to pots soil. The remaining half dose of $\mathrm{N}$ was applied at 30 days after planting (DaP) of seed potatoes.

The inoculation applications were started at $30 \mathrm{DaP}$. For pathogen inoculation, a spore suspension of $N$. rubicola was prepared in Tween- 80 solution $(0.9 \% \mathrm{NaCl}$ and $0.1 \%$ Tween $80)$. The spore count in the suspension was estimated by the hemocytometer as $5.35 \times 10^{6} \mathrm{~mL}^{-1}$. The suspension was applied to pot soil at $10 \mathrm{~mL}$ per pot followed by light irrigation to assure the spore penetration to the root zone. For BF preparation, FKJT biofertilizer was obtained from the Bacteriology section of AARI, which they claimed to have $1.2 \times 10^{6}$ colony-forming units (CFU) of A. chroococcum, A. lipoferum, P. putida on $1 \mathrm{~g}$ of a carrier material (Rafique et al., 2018). For a single pot, $5 \mathrm{~g}$ FKJT was suspended in $20 \mathrm{~mL}$ of $10 \%$ sugar solution and applied over the soil surface, followed by a light irrigation. In this way, the total CFU added to a pot was $6 \times 10^{6}$.

\section{Analysis of Changes in the Growth Parameters and Leaf Nutrients of the Potato}

At $65 \mathrm{DaP}$, a leaf, 4th from the growing tip, was sampled from each plant and analyzed for nitrate, potassium and phosphorous. Nitrate was water-extracted from the fresh leaf tissue and estimated through nitration of salicylic acid in the presence of concentrated sulfuric acid followed by optical density measurement at $410 \mathrm{~nm}$ (Cataldo et al., 1975). Dried leaves were digested in a 2:1 mixture of nitric acid and perchloric acid for $\mathrm{P}$ and $\mathrm{K}$ determinations. Ammonium heptamolybdate-ammonium vanadate and flame photometer methods were used for $\mathrm{P}$ and $\mathrm{K}$ estimation from the digests, respectively (Jones et al., 1991).

At $70 \mathrm{DaP}$, variables such as plant height, the total number of stems per pot, the number of stems with rot symptoms per pot and average stem width per pot were estimated. At maturity, the plants were harvested, tubers were dug up, and the total number of tubers per pot, the number of tubers with rot symptoms per pot and potato yield per pot were determined.

The pot experiments were conducted in three growing seasons under a rain shelter to block natural rainfall. The rain shelter was generally closed throughout growing seasons and opened only during rainfalls. The experimental results were averaged over growing seasons before applying statistical analysis. The data of all the variables were subjected to analysis of variance, and means were compared with Tukey's HSD test. The Pearson correlation between various analytical and growth variables was estimated by using Statistix 8.1 computer software. 


\section{RESULTS}

\section{Antifungal Activity of Selected PGPB Against $\mathbf{N}$. rubicola Radial Growth}

The dual culture technique was followed to evaluate three strains of PGPB against N. rubicola in Petri-plates. After 5 days of inoculation, the effect of PGPB on the radial growth of the fungus was significant. Maximum radial growth was observed in the treatment where the fungus was inoculated alone on PDA (control). Dual inoculation of "N. rubicola + A. chroococcum + P. putida" and "N. rubicola + A. chroococcum + A. lipoferum $+P$. putida" reduced radial growth of the fungus up to $91 \%$ in comparison to the control (Figure 1). Inoculating N. rubicola

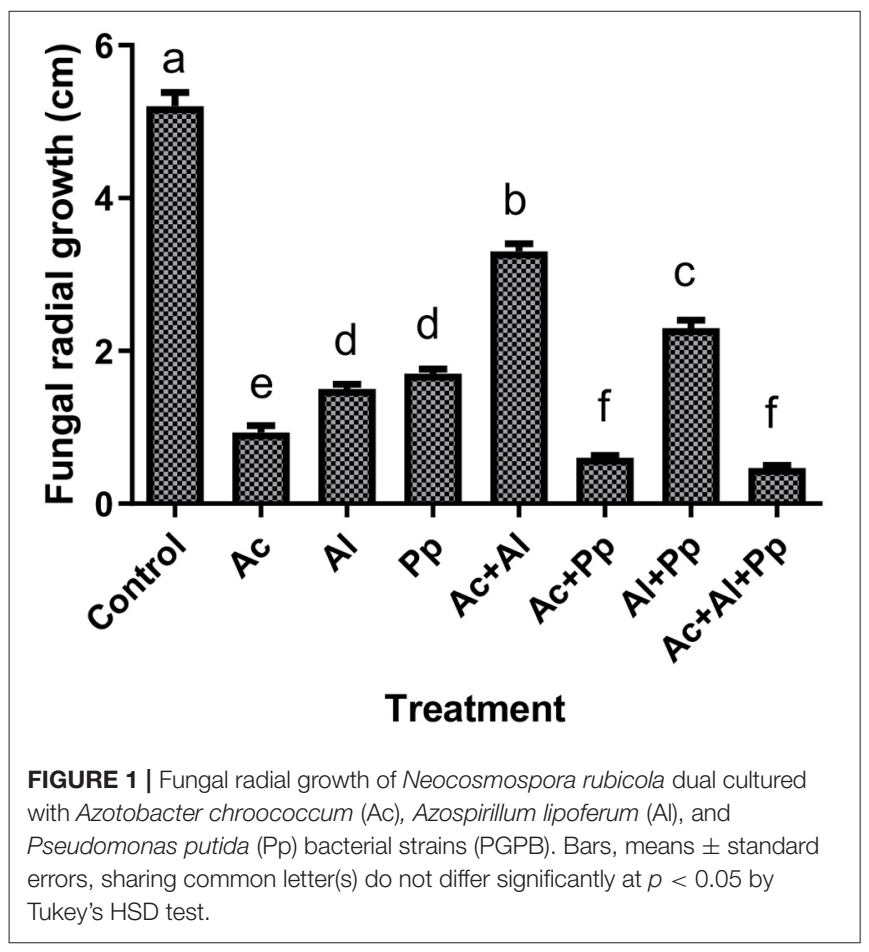

with a single PGPB of $A$. chroococcum, A. lipoferum, or P. putida caused radial growth inhibition up to 82,71 and $67 \%$, respectively (Figure 1).

\section{Effect of Synthetic Fertilizer and Inoculation With $\mathbf{N}$. rubicola and PGPB Formulation on Growth and Yield of Potato}

The significance levels ( $p$ values) of main effects and interactions in the analysis of variance are presented in Table 2. A highly significant difference was observed among fertilizer $\mathrm{N}$ levels for all variables and fertilizer $\mathrm{P}$ for the majority of the variables except the rot variables, i.e. the number of rotten stems and number of rotten tubers. In addition, there were highly significant differences among inoculation combinations (IC) for all measured variables.

Except for rotten stems (\%) and leaf nitrate, $\mathrm{N} \times \mathrm{P}$ interaction was non-significant for all parameters. There was no $\mathrm{N} \times \mathrm{IC}$ interaction for the number of stems, tubers, and tuber yield. However, the interaction existed for rotten stems (\%), rotten tubers (\%), plant height and stem diameter. There was no $\mathrm{P} \times \mathrm{IC}$ interaction for most variables except leaf nitrate, leaf phosphorus and the number of rotten tubers. A three-way interaction for $\mathrm{N}$ $\times \mathrm{P} \times \mathrm{IC}$ was found significant only for leaf nitrate contents (Table 2).

The means of variables measured for their response to $\mathrm{N}$ and P fertilizers are presented in Tables 3, 4, respectively. An increase in $\mathrm{N}$ from 125 to $250 \mathrm{~kg} \mathrm{ha}^{-1}$ decreased stem rot and increased the number, diameter, and height of stems by $10-14 \%$. 'This increment in $\mathrm{N}$ dose increased potato yield by $4 \%$ and tuber number by $6 \%$ and caused rot in $23 \%$ more tubers. Leaf nitrate contents of plants treated with $250 \mathrm{~kg} \mathrm{~N} \mathrm{ha}^{-1}$ were about $122 \%$ more than those supplied with a half dose of $\mathrm{N}\left(125 \mathrm{~kg} \mathrm{ha}^{-1}\right)$. Doubling the $\mathrm{N}$ dose also increased $\mathrm{K}$ and $\mathrm{P}$ in potato leaves by 3 and $15 \%$, respectively (Table 3 ).

An increase in P-fertilizer from 60 to $120 \mathrm{~kg} \mathrm{P}_{2} \mathrm{O}_{5} \mathrm{ha}^{-1}$ significantly increased $\mathrm{P}$, nitrate and $\mathrm{K}$ in potato leaves by 40,22 , and $11 \%$, respectively. In response to $120 \mathrm{~kg} \mathrm{P}_{2} \mathrm{O}_{5} \mathrm{ha}^{-1}$, potato stems were $2-4 \%$ greater in number, height, and diameter than those at $60 \mathrm{~kg} \mathrm{P}_{2} \mathrm{O}_{5} \mathrm{ha}^{-1}$. A similar response was noted for the

TABLE 2 | Probability levels of the variance ratio from analysis of variance of variables scored on two rates of fertilizer nitrogen (N) and fertilizer phosphorus (P), and six inoculation combinations (IC).

\begin{tabular}{|c|c|c|c|c|c|c|c|}
\hline Parameters & $\mathbf{N}$ & $\mathbf{P}$ & IC & $\mathbf{N} \times \mathbf{P}$ & $\mathbf{N} \times \mathbf{I C}$ & $P \times I C$ & $\mathbf{N} \times \mathbf{P} \times \mathbf{I C}$ \\
\hline Plant height & $<0.001$ & 0.014 & $<0.001$ & 0.133 & 0.001 & 0.318 & 0.458 \\
\hline Stem diameter & $<0.001$ & $<0.001$ & $<0.001$ & 0.265 & 0.009 & 0.338 & 0.368 \\
\hline No. of stems & $<0.001$ & 0.027 & $<0.001$ & 1.000 & 0.065 & 0.297 & 0.948 \\
\hline No. of rotted stems & $<0.001$ & 0.064 & $<0.001$ & 0.064 & 0.060 & 0.119 & 0.203 \\
\hline No. of tubers & $<0.001$ & 0.003 & $<0.001$ & 0.751 & 0.142 & 0.980 & 0.944 \\
\hline No. of rotted tubers & $<0.001$ & 0.102 & $<0.001$ & 0.188 & 0.204 & 0.038 & 0.225 \\
\hline Tuber yield & $<0.001$ & $<0.001$ & $<0.001$ & 0.330 & 0.375 & 0.907 & 0.220 \\
\hline Leaf nitrate & $<0.001$ & $<0.001$ & $<0.001$ & 0.009 & 0.002 & $<0.001$ & 0.020 \\
\hline Leaf phosphorus & $<0.001$ & $<0.001$ & $<0.001$ & 0.241 & 0.294 & 0.002 & 0.560 \\
\hline Leaf potassium & $<0.001$ & $<0.001$ & $<0.001$ & 0.467 & 0.830 & 0.320 & 0.846 \\
\hline
\end{tabular}

The bold values indicate the significance levels ( $p$ values) of main effects and interactions in the analysis of variance. 
TABLE 3 | Variations in potato plant growth, yield, and nutrient variables in response to nitrogen fertilizer.

\begin{tabular}{|c|c|c|c|}
\hline \multirow[t]{2}{*}{ Parameters } & \multicolumn{2}{|c|}{ Nitrogen fertilizer } & \multirow[t]{2}{*}{ HSD $(p<0.05)$} \\
\hline & $\begin{array}{l}\text { Half of } \\
\text { recommended } \\
\left(125 \mathrm{~kg} \mathrm{ha}^{-1}\right)\end{array}$ & $\begin{array}{c}\text { Recommended } \\
\left(250 \mathrm{~kg} \mathrm{ha}^{-1}\right)\end{array}$ & \\
\hline Plant height (cm) & $15.2 b^{*}$ & $16.7 \mathrm{a}$ & 0.26 \\
\hline Stem diameter (mm) & $6.4 \mathrm{~b}$ & $7.3 a$ & 0.13 \\
\hline No. of stems pot ${ }^{-1}$ & $12.6 b$ & $14.1 \mathrm{a}$ & 0.44 \\
\hline No. of rotted stems pot ${ }^{-1}$ & $3.2 \mathrm{a}$ & $2.7 \mathrm{~b}$ & 0.34 \\
\hline No. of tubers pot ${ }^{-1}$ & $19.5 b$ & $20.8 \mathrm{a}$ & 0.53 \\
\hline No. of rotted tubers pot ${ }^{-1}$ & $2.6 \mathrm{~b}$ & $3.2 \mathrm{a}$ & 0.33 \\
\hline Tuber yield $\left(\mathrm{kg} \mathrm{pot}^{-1}\right)$ & $0.71 \mathrm{~b}$ & $0.74 \mathrm{a}$ & 0.01 \\
\hline Leaf nitrate (ppm) & $5.3 \mathrm{~b}$ & $11.8 \mathrm{a}$ & 0.77 \\
\hline Leaf phosphorus (ppm) & 19.7 b & $22.8 \mathrm{a}$ & 1.04 \\
\hline Leaf potassium (\%) & $0.30 \mathrm{~b}$ & $0.31 \mathrm{a}$ & 0.006 \\
\hline
\end{tabular}

*Means sharing common letter(s) in a row do not differ significantly at $p<0.05$ by Tukey's HSD Test.

TABLE 4 | Variations in potato plant growth, yield, and nutrient variables in response to phosphorus fertilizer.

\begin{tabular}{|c|c|c|c|}
\hline \multirow[t]{2}{*}{ Parameters } & \multicolumn{2}{|c|}{ Fertilizer phosphorus } & \multirow[t]{2}{*}{ HSD $(p<0.05)$} \\
\hline & $\begin{array}{c}\text { Half of } \\
\text { recommended } \\
\left(60 \mathrm{~kg} \mathrm{ha}^{-1}\right)\end{array}$ & $\begin{array}{l}\text { Recommended } \\
\left(120 \mathrm{~kg} \mathrm{ha}^{-1}\right)\end{array}$ & \\
\hline Plant height (cm) & $15.8 b^{\star}$ & $16.1 \mathrm{a}$ & 0.26 \\
\hline Stem diameter (mm) & $6.7 \mathrm{~b}$ & $7.0 \mathrm{a}$ & 0.13 \\
\hline No. of stems pot ${ }^{-1}$ & $13.1 \mathrm{~b}$ & $13.6 \mathrm{a}$ & 0.44 \\
\hline No. of rotted stems pot ${ }^{-1}$ & $3.1 \mathrm{a}$ & $2.8 \mathrm{a}$ & 0.32 \\
\hline No. of tubers pot ${ }^{-1}$ & 19.8 b & $20.6 \mathrm{a}$ & 0.53 \\
\hline No. of rotted tubers pot ${ }^{-1}$ & $2.8 \mathrm{a}$ & $3.0 \mathrm{a}$ & 0.33 \\
\hline Tuber yield $\left(\mathrm{kg} \mathrm{pot}^{-1}\right)$ & $0.70 \mathrm{~b}$ & $0.72 \mathrm{a}$ & 0.01 \\
\hline Leaf nitrate (ppm) & $7.7 \mathrm{~b}$ & $9.4 \mathrm{a}$ & 0.77 \\
\hline Leaf phosphorus (ppm) & 17.7 b & $24.8 \mathrm{a}$ & 1.04 \\
\hline Leaf potassium (\%) & $0.27 \mathrm{~b}$ & $0.30 a$ & 0.006 \\
\hline
\end{tabular}

${ }^{\star}$ Means sharing common letter(s) in a row do not differ significantly at $p<0.05$ by Tukey's HSD Test.

number of tubers per pot and tuber yield. However, $\mathrm{P}$ addition had no significant effect on rot parameters, i.e., number of rotten stems and rotten tubers (Table 4).

The effect of inoculation of N. rubicola and BF on growth, yield and rot of tubers is presented in Table 5. Sole inoculation of $N$. rubicola significantly reduced plant height and number of stems per pot compared to the control. Maximum height and the number of stems were recorded in potato plants where BF was applied alone or 1 week prior to the inoculation of N. rubicola. Application of BF 1 week after inoculation of $N$. rubicola did not increase plants' height and the number of stems compared to control. However, a combined inoculation of N. rubicola and $\mathrm{BF}$ increased plant height by $10 \%$ compared to that of noninoculated, and $27 \%$ compared to that inoculated with N. rubicola alone (Table 5).
The minimum number of rotten stems and tubers were observed in the absence of $N$. rubicola inoculation, followed by $\mathrm{BF}$ application a week prior to the pathogen inoculation and a combined inoculation of $N$. rubicola and BF. Sole inoculation of N. rubicola, or its inoculation a week prior to BF, caused the maximum number of rotten stems and tubers (Table 5).

Compared to the control, tuber yield decreased with N. rubicola inoculation by $11 \%$ and increased with BF by $41 \%$. Inoculation of $N$. rubicola a week prior to or combined with BF did not affect tuber yield compared to the control. The pathogen had no effects on tuber yield when it was inoculated a week prior to $\mathrm{BF}$ application. Bacterial formulation increased tuber yield by $32 \%$ in comparison to the control (Table 5).

N. rubicola significantly decreased, and $\mathrm{BF}$ increased nitrate, $\mathrm{P}$ and $\mathrm{K}$ contents in potato leaves. These contents were maximum with sole BF application, followed by BF application a week prior to N. rubicola, and a combined application of both. Leaf nitrate, $\mathrm{P}$ and $\mathrm{K}$ were found to be minimal with $N$. rubicola alone, which were similar to when N. rubicola was applied a week prior to the BF (Table 5).

$\mathrm{N}, \mathrm{P}$, and $\mathrm{K}$ concentrations were negatively correlated with the number of rotten stems and tubers (Table 6). However, a highly significant and positive correlation $(r=0.91)$ was observed between the number of rotten stems and tubers. In the same way, there were significant positive correlations between nitrate, $\mathrm{P}$ and $\mathrm{K}$ concentrations in potato leaves (Table 6).

The interaction effect of treatments and $\mathrm{P}$ fertilizer on the number of rotten tubers is presented in Figure 2. Tuber rot due to sole inoculation of $N$. rubicola was not influenced by $\mathrm{P}$ fertilizer doses. However, an increase in $\mathrm{P}$ fertilizer dose along with $\mathrm{BF}$ application significantly reduced the number of rotten tubers in the treatments where the pathogen was applied.

\section{DISCUSSION}

The radial growth-suppression of $N$. rubicola in the PDA medium seemed to be related to the production of anti-fungal compounds by the PGPB strains. These compounds might be hydrocyanic acid (HCN) produced by A. chroococcum (Gopalakrishnan et al., 2011), salicylic acid, 2,3-dihydroxybenzoic acid (DHBA), and 3,5DHBA conjugated with threonine and lysine by A. lipoferum (Shah et al., 1992), and volatile organics belonging to pyrazines such as 2-methylpyrazine and 2-ethyl-3,6-dimethylpyrazine by P. putida (Patel et al., 2021). Owing to the production of these compounds, and strengthening the plants by phosphate solubilization, nitrogen fixation, and producing siderophores, indole acetic acid (IAA), gibberellins, cytokinins, and vitamins (Gopalakrishnan et al., 2011; Seddigui Kiasari et al., 2018; Mehmood et al., 2021), these PGPB are already reported to have anti-fungal activity against common scabs of potato (Sowanpreecha and Rerngsamran, 2018), late blight of potato (Hultberg et al., 2010), Fusarium wilt of radish and some other plant diseases caused by soil-borne fungi (Weller, 2007).

Plants grown under the recommended dose of fertilizers showed better growth and yield than those supplied with halfdose, solely due to nutrient sufficiency and behavioral response 
TABLE 5 | Variations in potato plants' growth, yield, and nutrient variables in response to soil inoculation with various combinations of Neocosmospora rubicola (Nr) and the bacterial formulation (BF).

\begin{tabular}{|c|c|c|c|c|c|c|c|}
\hline Parameters & Control & $\mathrm{Nr}$ & BF & $N r+B F$ & BF followed $\mathrm{Nr}$ & Nr followed BF & HSD $(p<0.05)$ \\
\hline Plant height (cm) & $14.9 c^{\star}$ & $12.9 d$ & $19.5 a$ & 16.4 b & $14.7 \mathrm{c}$ & $18.3 a$ & 0.65 \\
\hline Stem diameter (mm) & $6.8 \mathrm{c}$ & $5.6 \mathrm{~d}$ & $8.3 \mathrm{a}$ & $6.6 \mathrm{c}$ & $5.9 \mathrm{~d}$ & $7.8 \mathrm{~b}$ & 0.33 \\
\hline No. of stems pot ${ }^{-1}$ & $13.4 \mathrm{~cd}$ & $10.3 \mathrm{e}$ & $15.6 \mathrm{a}$ & $13.9 \mathrm{bc}$ & $12.3 d$ & $14.6 \mathrm{ab}$ & 1.13 \\
\hline No. of rotted stems pot ${ }^{-1}$ & $0.5 \mathrm{~d}$ & $7.1 \mathrm{a}$ & $0.6 \mathrm{~d}$ & $5.4 \mathrm{~b}$ & $7.3 a$ & $2.08 \mathrm{c}$ & 0.75 \\
\hline No. of tubers pot ${ }^{-1}$ & $20.5 b$ & $15.5 \mathrm{~d}$ & $23.6 \mathrm{a}$ & $20 \mathrm{bc}$ & $18.4 \mathrm{c}$ & $22.5 \mathrm{~d}$ & 1.35 \\
\hline No. of rotted tubers pot ${ }^{-1}$ & $0.33 c$ & $6.0 \mathrm{a}$ & $0.33 c$ & $4.4 \mathrm{~b}$ & $5.2 \mathrm{ab}$ & $1.1 \mathrm{C}$ & 0.86 \\
\hline Tuber yield $\left(\mathrm{kg} \mathrm{pot}^{-1}\right)$ & $0.61 \mathrm{~d}$ & $0.54 f$ & $0.86 a$ & $0.75 d$ & $0.61 d$ & $0.81 \mathrm{~b}$ & 0.027 \\
\hline Leaf nitrate (ppm) & 10.6 b & $5.8 \mathrm{~cd}$ & $15.9 a$ & $7.57 \mathrm{c}$ & $4.43 \mathrm{~d}$ & $10.6 \mathrm{~b}$ & 1.97 \\
\hline Leaf phosphorus (ppm) & 20.7 b & $10.9 d$ & $30.2 a$ & $21.3 b$ & $16.3 c$ & $28.1 \mathrm{a}$ & 2.65 \\
\hline Leaf potassium (\%) & $0.28 \mathrm{~b}$ & $0.24 \mathrm{~d}$ & $0.34 a$ & 0.29 b & $0.26 \mathrm{c}$ & $0.31 \mathrm{a}$ & 0.02 \\
\hline
\end{tabular}

"Means sharing common letter(s) in a row do not differ significantly at $p<0.05$ by Tukey's HSD test.

TABLE 6 | Correlation coefficients (Pearson) among leaf nutrient status and various rotting variables of potato.

\begin{tabular}{lcccc}
\hline Parameters & Leaf nitrate & Leaf P & Leaf K & Rotted stems \\
\hline Leaf P & $0.59^{\star \star}$ & & & \\
Leaf K & $0.32^{\star}$ & $0.46^{\star \star}$ & & \\
Rotted stems & $-0.60^{\star *}$ & $-0.66^{\star \star}$ & $-0.26^{\star}$ & \\
Rotted potatoes & $-0.57^{\star}$ & $-0.70^{\star \star}$ & $-0.29^{\star}$ & $0.91^{\star \star}$ \\
\hline
\end{tabular}

** Significant at $p<0.001,{ }^{*}$ Significant at $p<0.05$.

of nutrient-deficient plants to nutrient applications (Baligar et al., 2001). Nitrogen and phosphorus applications enhanced their synergistic uptake along with potassium, as indicated by a significant positive correlation between nitrogen, phosphorus and potassium concentrations in potato leaves. This synergistic behavior of $\mathrm{N}, \mathrm{P}$, and $\mathrm{K}$ is well-documented in the literature for several crop plants (Binder et al., 2000; Zhang et al., 2010).

Soil inoculation of $N$. rubicola significantly reduced potato growth and yield by rotting the stems and tubers. This reduction in growth and yield variables of potatoes was caused by the disintegration of vascular bundles, which restricted the ability of potatoes to uptake and distributed nutrients and water (Chavarria and dos Santos, 2012). The detrimental effects of $N$. rubicola on nutrient uptake were also evident from the negative correlation of $\mathrm{N}, \mathrm{P}$, and $\mathrm{K}$ concentrations in potato leaves with the number of rotten stems and tubers (Table 6). The report of $N$. rubicola as a causal agent of stem rot of potatoes is relatively recent (Riaz et al., 2020). However, it was previously found to cause rots and severe yield reductions in Hylocereus undatus (Zheng et al., 2018), Glycyrrhiza uralensis (Kim et al., 2017), and Pyrus spp. (An et al., 2016).

The application of $\mathrm{BF}$ increased potato growth and yield possibly due to (i) nitrogen fixation by $A$. chroococcum and A. lipoferum, particularly more important in nitrogendeficient plants (Cassán and Diaz-Zorita, 2016; Gothandapani et al., 2017), (ii) phosphate solubilization by $P$. putida (Sowanpreecha and Rerngsamran, 2018), (iii) production of

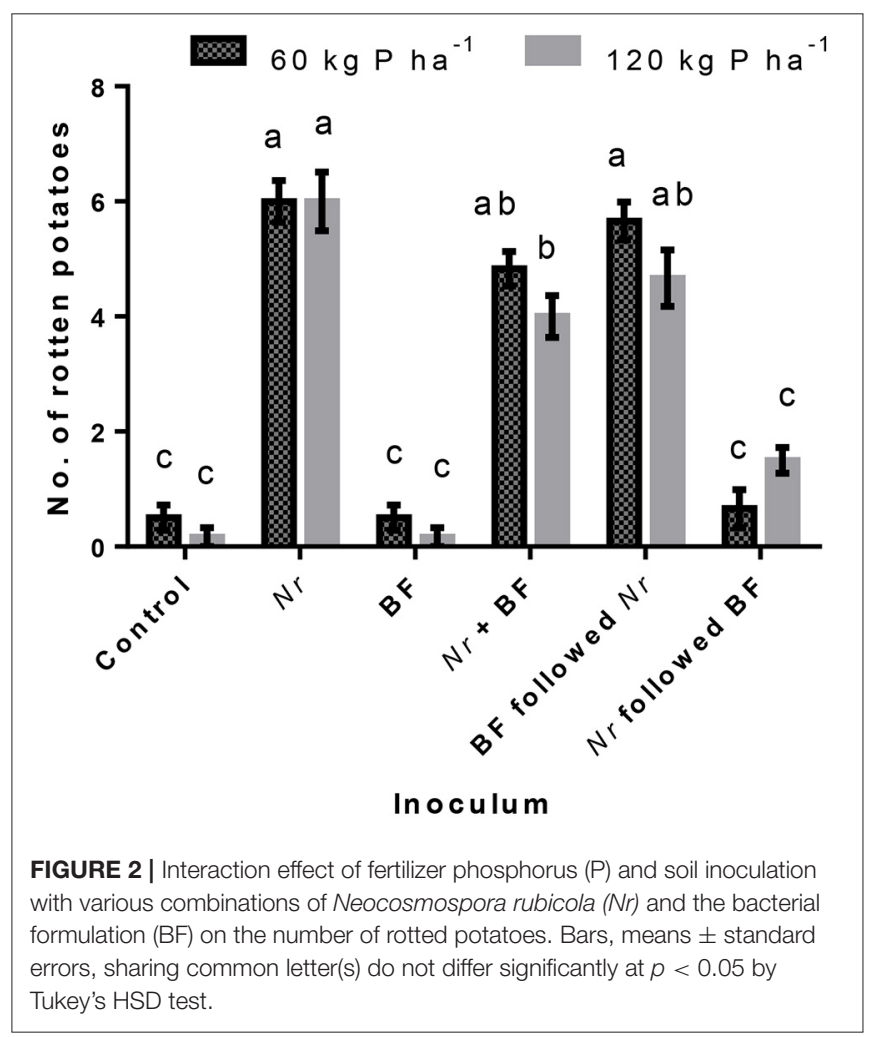

growth promoters/hormones in the rhizosphere (Gothandapani et al., 2017), and (iv) biological suppression of N. rubicola in infested soil to minimize rot incidence and severity (Sowanpreecha and Rerngsamran, 2018). The BF-induced N fixation and $\mathrm{P}$ solubilization were evident from the increase in $\mathrm{N}$ and $\mathrm{P}$ concentrations in potato plants.

Application of the BF a week prior to N. rubicola inoculation nullified the effect of pathogen and increased potato growth and yield compared to the control. In contrast, $N$. rubicola inoculation a week prior to BF masked the positive impact of $\mathrm{BF}$ under detrimental pathogenic effects. However, a combined 
inoculation of the pathogen and the BF neither enhanced nor reduced potato yield. These responses indicated that the $\mathrm{BF}$ could potentially encounter detrimental effects of $N$. rubicola on potato plants, mainly when applied prior to disease occurrence. Furthermore, the BF strengthened plants against disease incident and severity through better and balanced nutrition and by providing plant growth hormones (Ouhaibi-Ben Abdeljalil et al., 2016).

Nitrogen decreased the number of rotten stems and increased the number of rotten potatoes. This behavior of the pathogen should be further explored. However, it can be hypothesized that $\mathrm{N}$-induced rapid growth of potato stems better tolerated destructive effects of the fungal pathogen (Mackenzie, 1981). In contrast, high $\mathrm{N}$ concentration reduced tuber-specific gravity to promote tuber rot (Wilson et al., 2019).

Increasing fertilizer-P in the presence of $\mathrm{BF}$ significantly reduced the number of rotten potatoes associated with treatments where the pathogen influence was significant. This indicated that inorganic $\mathrm{P}$ could have a synergistic impact on bacterial strains of the BF, particularly on A. lipoferum (Eftekhari et al., 2012), which suppressed the pathogen through its biocontrol potential (Mazhar et al., 2016).

\section{CONCLUSION}

Bacterial formulation (BF) containing strains of A. chroococcum, A. lipoferum and $P$. putida has the potential to increase the tuber yield of potato in healthy soil as well as in the soil infested with $N$. rubicola. Phosphorus applications along with the BF can improve the working efficiency of the bacterial strains. However, nitrogen fertilizer can favor $N$. rubicola infestation

\section{REFERENCES}

An, Y., Li, J., Duan, C., Liu, L., Sun, Y., Cao, R., et al. (2016). 5-Aminolevulinic acid thins pear fruits by inhibiting pollen tube growth via Ca2+-ATPase-mediated Ca2+ efflux. Front. Plant Sci. 7, 121. doi: 10.3389/fpls.2016.00121

Anith, K., Nysanth, N., and Natarajan, C. (2021). Novel and rapid agar plate methods for in vitro assessment of bacterial biocontrol isolates' antagonism against multiple fungal phytopathogens. Lett. Appl. Microbiol. 73, 229-236. doi: 10.1111/lam.13495

Antar, M., Gopal, P., Msimbira, L. A., Naamala, J., Nazari, M., Overbeek, W., et al. (2021). "Inter-organismal signaling in the rhizosphere," in Rhizosphere Biology: Interactions Between Microbes and Plants (Singapore: Springer), 255-293.

Baligar, V., Fageria, N., and He, Z. (2001). Nutrient use efficiency in plants. Commun. Soil Sci. Plant Anal. 32, 921-950. doi: 10.1081/CSS-100104098

Batabyal, B. (2021). Azospirillum: Diversity, distribution, and biotechnology applications. Int. J. Pharm. Life Sci. 12, 17-25. Available online at: http://www. ijplsjournal.com/issues\%20PDF\%20files/Archive-2021/January-2021/3.pdf (accessed January 21, 2021).

Bernal, P., Allsopp, L. P., Filloux, A., and Llamas, M. A. (2017). The Pseudomonas putida T6SS is a plant warden against phytopathogens. ISME J. 11, 972-987. doi: 10.1038/ismej.2016.169

Besser, H., and Hamed, Y. (2021). Environmental impacts of land management on the sustainability of natural resources in Oriental Erg Tunisia, North Africa. Environ. Dev. Sustain. 23, 11677-11705. doi: 10.1007/s10668-020-01135-9

Binder, D. L., Sander, D. H., and Walters, D. T. (2000). Maize response to time of nitrogen application as affected by level of nitrogen deficiency. Agron. J. 92, 1228-1236. doi: 10.2134/agronj2000.9261228x without interfering with the working of the strains. To control $N$. rubicola infestation, with maximum tuber yield benefits, a preapplication of the biofertilizer is a better option. However, this study calls for future research to verify experimental results in different types of soils, in open field crops and under different pedoclimatic conditions.

\section{DATA AVAILABILITY STATEMENT}

The datasets presented in this study can be found in online repositories. The names of the repository/repositories and accession number(s) can be found at: NCBI [accession: KM231799 and KM232061].

\section{AUTHOR CONTRIBUTIONS}

MR: conceptualized the study, formal analysis, methodology, and writing of original draft/manuscript. RM: designing of survey format and compilation and interpretation of data. SK: review and editing, supervision, and technical input. NA: supervised, reviewed, and edited the manuscript and provided technical guidelines during the study. MAA: field visits for collection of data and provided the biofertilizer. MA: technical input and edited the manuscript. DS: review and editing, supervision, and technical input. All authors contributed to the article and approved the submitted version.

\section{FUNDING}

This work was funded through support from the University of the Punjab, Lahore.

Borrero De Acuña, J. M., and Bernal, P. (2021). Plant holobiont interactions mediated by the type VI secretion system and the membrane vesicles: promising tools for a greener agriculture. Environ. Microbiol. 23, 1830-1836. doi: 10.1111/1462-2920.15457

Cassán, F., and Diaz-Zorita, M. (2016). Azospirillum sp. in current agriculture: from the laboratory to the field. Soil Biol. Biochem. 103, 117-130. doi: 10.1016/j.soilbio.2016.08.020

Cataldo, D., Maroon, M., Schrader, L. E., and Youngs, V. L. (1975). Rapid colorimetric determination of nitrate in plant tissue by nitration of salicylic acid. Commun. Soil Sci. Plant Anal. 6, 71-80. doi: 10.1080/00103627509366547

Çevik, Y. N., and Ogutcu, H. (2020). Identification of bacteria in soil by MALDITOF MS and analysis of Bacillus spp., Paenibacillus spp. and Pseudomonas spp. with PCA. Anal. Chem. Lett. 10, 784-797. doi: 10.1080/22297928.2021.1877194

Chandra, H., Kumari, P., Bisht, R., Prasad, R., and Yadav, S. (2020). Plant growth promoting Pseudomonas aeruginosa from Valeriana wallichii displays antagonistic potential against three phytopathogenic fungi. Mol. Biol. Rep. 47, 6015-6026. doi: 10.1007/s11033-020-05676-0

Chavarria, G., and dos Santos, H. P. (2012). "Plant water relations: Absorption, transport and control mechanisms," in Advances in Selected Plant Physiology Aspects (London: IntechOpen).

Czarnes, S., Mercier, P. E., Lemoine, D. G., Hamzaoui, J., and Legendre, L. (2020). Impact of soil water content on maize responses to the plant growth-promoting rhizobacterium Azospirillum lipoferum CRT1. J. Agron. Crop Sci. 206, 505-516. doi: $10.1111 /$ jac.12399

Dahal, K., Li, X.-Q., Tai, H., Creelman, A., and Bizimungu, B. (2019). Improving potato stress tolerance and tuber yield under a climate change scenario-a current overview. Front. Plant Sci. 10, 563. doi: 10.3389/fpls.2019.00563 
Durán, D., Bernal, P., Vazquez-Arias, D., Blanco-Romero, E., Garrido-Sanz, D., Redondo-Nieto, M., et al. (2021). Pseudomonas fluorescens F113 type VI secretion systems mediate bacterial killing and adaption to the rhizosphere microbiome. Sci. Rep. 11, 1-13. doi: 10.1038/s41598-021-85218-1

Eftekhari, S. A., Ardakani, M., Rejali, F., Paknejad, F., and Hasanabadi, T. (2012). Phosphorus absorption in barley (Hordeum vulgare L.) under different phosphorus application rates and co-inoculation of Pseudomonas fluorescence and Azospirillum lipoferum. Ann. Biol. Res. 3, 2694-2702.

Gopalakrishnan, S., Humayun, P., Kiran, B. K., Kannan, I. G. K., Vidya, M. S., Deepthi, K., et al. (2011). Evaluation of bacteria isolated from rice rhizosphere for biological control of charcoal rot of sorghum caused by Macrophomina phaseolina (Tassi) Goid. World J. Microbiol. Biotechnol. 27, 1313-1321. doi: 10.1007/s11274-010-0579-0

Gothandapani, S., Sekar, S., and Padaria, J. C. (2017). Azotobacter chroococcum: utilization and potential use for agricultural crop production: an overview. Int. J. Adv. Res. Biol. Sci 4, 35-42. doi: 10.22192/ijarbs.2017.04.03.004

Hultberg, M., Bengtsson, T., and Liljeroth, E. (2010). Late blight on potato is suppressed by the biosurfactant-producing strain Pseudomonas koreensis 2.74 and its biosurfactant. Biocontrology 55, 543-550. doi: 10.1007/s10526-010-9289-7

Jones, Jr, J. B., Wolf, B., and Mills, H. A. (1991). Plant Analysis Handbook: A Practical Sampling, Preparation, Analysis, and Interpretation Guide. Athens, GA: Micro-Macro Publishing.

Khruengsai, S., Pripdeevech, P., Tanapichatsakul, C., Srisuwannapa, C., D'souza, P. E., and Panuwet, P. (2021). Antifungal properties of volatile organic compounds produced by Daldinia eschscholtzii MFLUCC 19-0493 isolated from Barleria prionitis leaves against Colletotrichum acutatum and its post-harvest infections on strawberry fruits. PeerJ 9, e11242. doi: $10.7717 /$ peerj. 11242

Kim, J.-H., Kim, D.-Y., Park, H., Cho, J. H., and Eom, A.-H. (2017). Neocosmospora rubicola, an unrecorded endophytic fungus isolated from roots of Glycyrrhiza uralensis in Korea. Korean J. Mycol. 45, 63-67. doi: 10.4489/KJM.20170007

Kumar, V., Anal, A. K. D., and Nath, V. (2018). Growth response of litchi to arbuscular mycorrhizal co-inoculation with Trichoderma viride, Azotobacter chroococcum and Bacillus megatarium. Indian Phytopathol. 71, 65-74. doi: 10.1007/s42360-018-0010-6

Kumari, P., Bishnoi, S. K., and Chandra, S. (2021). Assessment of antibiosis potential of Bacillus sp. against the soil-borne fungal pathogen Sclerotium rolfsii Sacc. (Athelia rolfsii (Curzi) Tu \& Kimbrough). Egyptian J. Biol. Pest Control 31, 1-11. doi: 10.1186/s41938-020-00350-w

Liu, Y., Pan, X., and Li, J. (2015). A 1961-2010 record of fertilizer use, pesticide application and cereal yields: a review. Agron. Sustain. Dev. 35, 83-93. doi: 10.1007/s13593-014-0259-9

Mackenzie, D. (1981). Association of potato early blight, nitrogen fertilizer rate, and potato yield. Plant Dis. 65, 575-577. doi: 10.1094/PD-65-575

Maheshwari, D., Dubey, R., Aeron, A., Kumar, B., Kumar, S., Tewari, S., et al. (2012). Integrated approach for disease management and growth enhancement of Sesamum indicum L. utilizing Azotobacter chroococcum TRA2 and chemical fertilizer. World Journal of Microbiol. Biotechnol. 28, 3015-3024. doi: 10.1007/s11274-012-1112-4

Mazhar, R., Ilyas, N., Saeed, M., Bibi, F., and Batool, N. (2016). Biocontrol and salinity tolerance potential of Azospirillum lipoferum and its inoculation effect in wheat crop. Int. J. Agri. Biol. 18, 1-7. doi: 10.17957/IJAB/15.0115

Mehmood, T., Li, G., Anjum, T., and Akram, W. (2021). Azospirillum lipoferum strain AL-3 reduces early blight disease of potato and enhance yield. Crop Prot. 139, 105349. doi: 10.1016/j.cropro.2020.105349

Meliani, A., Bensoltane, A., Benidire, L., and Oufdou, K. (2017). Plant growthpromotion and IAA secretion with Pseudomonas fluorescens and Pseudomonas putida. Res. Rev. J. Bot. Sci. 6, 16-24.

Mohammadi, K., and Sohrabi, Y. (2012). Bacterial biofertilizers for sustainable crop production: a review. ARPN J. Agric. Biol. Sci. 7, 307-316.

Muhammad, R., Shah, M., Zaigham, N., Ateeq, T., Laila, S., Amina, B., et al. (2018). Influence of abiotic factors on growth and sporulation of Neocosmospora rubicola associated with stem rot of potato in Punjab, Pakistan. Mycopath $16,87-90$.

My, N. H., Demont, M., and Verbeke, W. (2021). Inclusiveness of consumer access to food safety: evidence from certified rice in Vietnam. Global Food Security 28, 100491. doi: 10.1016/j.gfs.2021.100491
Ouhaibi-Ben Abdeljalil, N., Vallance, J., Gerbore, J., Rey, P., and DaamiRemadi, M. (2016). Bio-suppression of Sclerotinia stem rot of tomato and biostimulation of plant growth using tomato-associated rhizobacteria. J. Plant Pathol. Microbiol. 7, 2. doi: 10.4172/2157-7471.1000331

PARC-Pakistan Agriculture Research Council. (2002). Seasonal Potato in Punjab. Available online at: http://www.parc.gov.pk/index.php/en/farmer-section/154urdu-m/vegetables-m/1104-seasonal-potato-in-punjab

Park, Y.-J., Kwon, O.-C., Son, E.-S., Yoon, D.-E., Han, W., Nam, J.-Y., et al. (2012). Genetic diversity analysis of Ganoderma species and development of a specific marker for identification of medicinal mushroom Ganoderma lucidum. Afr. J. Microbiol. Res. 6, 5417-5425. doi: 10.5897/AJMR12.846

Patel, A., Kumar, A., Sheoran, N., Kumar, M., Sahu, K. P., Ganeshan, P., et al. (2021). Antifungal and defense elicitor activities of pyrazines identified in endophytic Pseudomonas putida BP25 against fungal blast incited by Magnaporthe oryzae in rice. J. Plant Dis. Protection 128, 261-272. doi: 10.1007/s41348-020-00373-3

Paterson, E., and Mwafulirwa, L. (2021). "Root-soil-microbe interactions mediating nutrient fluxes in the rhizosphere," in Rhizosphere Biology: Interactions Between Microbes and Plants. (Singapore: Springer), 75-91.

Pellegrini, M., Ercole, C., Di Zio, C., Matteucci, F., Pace, L., and Del Gallo, M. (2020). In vitro and in planta antagonistic effects of plant growthpromoting rhizobacteria consortium against soilborne plant pathogens of Solanum tuberosum and Solanum lycopersicum. FEMS Microbiol. Lett. 367, fnaa099. doi: 10.1093/femsle/fnaa099

Rafique, M., Riaz, A., Anjum, A., Qureshi, M. A., and Mujeeb, F. (2018). Role of Bioinoculants for Improving Growth and Yield of Okra (Abelmoshus esculentum). Univers. J. Agri. Res. 6, 105-112. doi: 10.13189.UJAR.2018.060302

Riaz, M., Akhtar, N., Khan, S. N., Shakeel, M., and Tahir, A. (2020). Neocosmospora rubicola: an unrecorded pathogen from Pakistan causing potato stem rot. Sarhad J. Agric. 36, 906-912. doi: 10.17582/journal.sja/2020/36.3.906.912

Seddigui Kiasari, A., Aminpanah, H., and Sharifi, P. (2018). Chemical weed control in paddy fields inoculated with Azospirillum lipoferum. Planta Daninha 36. doi: 10.1590/s0100-83582018360100085

Sepehrnush, S., Amini, J., and Abdoulahzadeh, J. (2018). Morphological and molecular study of fungi isolated from potato crown, root and tuber in Kurdistan province. J. Appl. Res. Plant Protection 7, 47-66.

Shafique, S., Shafique, S., Sahar, S., and Akhtar, N. (2019). First report of Cladosporium cladosporioides instigating leaf spot of Solanum melongena from Pakistan. Pak. J. Bot. 51, 755-759. doi: 10.30848/PJB2019-2(43)

Shah, S., Karkhanis, V., and Desai, A. (1992). Isolation and characterization of siderophore, with antimicrobial activity, from Azospirillum lipoferum M. Curr. Microbiol. 25, 347-351. doi: 10.1007/BF01577233

Smith, D. L., Praslickova, D., and Ilangumaran, G. (2015). Inter-organismal signaling and management of the phytomicrobiome. Front. Plant Sci. 6, 722. doi: $10.3389 /$ fpls.2015.00722

Song, Y., Li, Z., Liu, J., Zou, Y., Lv, C., and Chen, F. (2021). Evaluating the impacts of Azotobacter chroococcum inoculation on soil stability and plant property of maize crop. J. Soil Sci. Plant Nutr. 21, 824-831. doi: 10.1007/s42729-020-00404-w

Sowanpreecha, R., and Rerngsamran, P. (2018). Biocontrol of orchidpathogenic mold, Phytophthora palmivora, by antifungal proteins from Pseudomonas aeruginosa RS1. Mycobiology 46, 129-137. doi: 10.1080/12298093.2018.1468055

Sun, D., Zhuo, T., Hu, X., Fan, X., and Zou, H. (2017). Identification of a Pseudomonas putida as biocontrol agent for tomato bacterial wilt disease. Biol. Control 114, 45-50. doi: 10.1016/j.biocontrol.2017.07.015

Tafesse, S., and Leta, S. (2019). Effect of municipal solid waste compost, farm yard manure, inorganic fertilizers and their combinations on potato yield in Wolmera District, Ethiopia. J. Agri. Ecol. Res. Int. 18, 1-9. doi: 10.9734/jaeri/2019/v18i230054

Takishita, Y., Souleimanov, A., Bourguet, C., Ohlund, L. B., Arnold, A. A., Sleno, L., et al. (2021). Pseudomonas entomophila 23S produces a novel antagonistic compound against Clavibacter michiganensis subsp. michiganensis, a pathogen of tomato bacterial canker. Appl. Microbiol. 1, 60-73. doi: 10.3390/applmicrobiol1010006

Weller, D. M. (2007). Pseudomonas biocontrol agents of soilborne pathogens: looking back over 30 years. Phytopathology 97, 250-256. doi: 10.1094/PHYTO-97-2-0250 
Wilson, C., Zebarth, B. J., Burton, D. L., Goyer, C., Moreau, G., and Dixon, T. (2019). Effect of diverse compost products on potato yield and nutrient availability. Am. J. Potato Res. 96, 272-284. doi: 10.1007/s12230-01909714-x

Zhang, F., Niu, J., Zhang, W., Chen, X., Li, C., Yuan, L., et al. (2010). Potassium nutrition of crops under varied regimes of nitrogen supply. Plant Soil 335, 21-34. doi: 10.1007/s11104-0100323-4

Zheng, F., Xu, G., Zheng, F., Ding, X., and Xie, C. (2018). Neocosmospora rubicola causing stem rot of pitaya (Hylocereus costaricensis) in China. Plant Dis. 102, 2653-2653. doi: 10.1094/PDIS-09-17-1469-PDN

Conflict of Interest: The authors declare that the research was conducted in the absence of any commercial or financial relationships that could be construed as a potential conflict of interest.
Publisher's Note: All claims expressed in this article are solely those of the authors and do not necessarily represent those of their affiliated organizations, or those of the publisher, the editors and the reviewers. Any product that may be evaluated in this article, or claim that may be made by its manufacturer, is not guaranteed or endorsed by the publisher.

Copyright (c) 2022 Riaz, Mahmood, Antar, Akhtar, Khan, Anjum and Smith. This is an open-access article distributed under the terms of the Creative Commons Attribution License (CC BY). The use, distribution or reproduction in other forums is permitted, provided the original author(s) and the copyright owner(s) are credited and that the original publication in this journal is cited, in accordance with accepted academic practice. No use, distribution or reproduction is permitted which does not comply with these terms. 